\title{
A constructivist approach to learning an interactive multimedia course: Malaysian students' perspectives
}

\author{
Mai Neo, Tse-Kian Neo and Gillian Tan Xiao-Lian \\ Multimedia University, Malaysia
}

\begin{abstract}
We present an alternative method in the constructive perspective to enhance student learning through a multimedia project, in which computing and multimedia technologies are used to enable students to participate more actively in their own learning. Students in a second year course in the Multimedia University, Malaysia, used the multimedia development process (MDP) to build a project in a collaborative, problem solving learning environment. They worked in groups and sought to solve their design problems as a team, with the teacher acting as a facilitator supporting them in their learning. Results showed that this method enhanced learning and improved understanding of the subject.
\end{abstract}

\section{Introduction: The constructivist approach}

Business, industry, the military and educational institutions have recognised the potential for using computers as instructional tools. The Malaysian Government's initiative, Vision 2020, has called for schools and institutions of higher education in Malaysia to integrate technology into the classroom and in the curricula. Mat (2000) proposed that Malaysian educationists be proactive towards incorporating technology into the teaching and learning environment. In such an environment, students will experience new challenges in technology and need to be versatile in adoption:

Information and communication technology (ICT) provides powerful tools for accessing, storing, and disseminating information... Our approaches to teaching, preparing contents and delivering learning materials need to be adjusted according to the existence of this technology. The classroom is no more a static physical set-up, but a rather dynamic existence... Teachers should be able to integrate technology in their process of teaching and learning..." (Mat, 2000) 
In the traditional education realm, the role of the teacher is to provide the content and information to the students, through instructional media such as notes, diagrams, overhead transparencies, models and more. The information or content that is presented is based on the teacher's curriculum and other relevant information for the class. With the introduction of multimedia into various industries, many educators began to see computers as part of a combination of technology resources, which included media elements such as text, graphics, sound, video and animations, instructional systems, and computer based support systems. Multimedia is the combination of various digital media types such as text, images, sound and video, into an integrated, multi-sensory, interactive application or presentation, to convey a message or information to an audience. In other words, multimedia means "an individual or a small group using a computer to interact with information that is represented in several media, by repeatedly selecting what to see and hear next" (Agnew, Kellerman \& Meyer, 1996).

At the heart of any digital multimedia development is interactivity. Interactivity in a multimedia application can be either linear or non-linear. With linear multimedia, there are no interactive features embedded into the design and the user simply navigates through the application in a sequential manner, whereas with non-linear multimedia, interactive features are embedded and the user can navigate to any part of the application in a non-sequential manner. With such interactivity, the audience is involved in the communication process and in the navigation of the content. Research suggests that people remember $20 \%$ of what they see, $40 \%$ of what they see and hear, and about $75 \%$ of what they see, hear and do simultaneously (Lindstrom 1994). Therefore, these types of interactivity and interactive features in a multimedia application facilitate interaction between the computer and the user, and increases user engagement (Bates \& Poole, 2003).

Lindstrom (1994) stated that, "Multimedia provides a means to supplement a presenter's efforts to garner attention, increase retention, improve comprehension, and to bring an audience into agreement." In the light of this, educators can take advantage of the multi-sensory environment created by the multiple digital media elements to create multimedia education materials that would not only stimulate a variety of senses from the audience, but also elicit high attention and retention rates from them. This alliance of sophisticated computing hardware and software technologies provides educators with a powerful toolset for creating multimedia courseware content (Neo \& Neo, 2004). Tway (1995) posits that "Multimedia offers an excellent alternative to traditional teaching. By allowing the students to explore and learn at different paces, every student has the opportunity to learn at his or her full potential." Multimedia is now 
penetrating the education field and changing the way teachers teach and students learn. With the advent of multimedia and technology in the classrooms, teachers can equip themselves with these technological skills and become better communicators of their content materials, thus enabling the students to learn in a more productive way (Zheng \& Zhou, 2006).

Thus educational curricula are evolving to incorporate multimedia elements and interactive features that create a better learning and teaching environment for the students as well as the teachers. By integrating multimedia technologies into education, we will be better able to produce a workforce that can meet the needs of the 21st century. The infusion of ICT and multimedia technology into education has created a significant impact on the instructional content development and the methods of communicating information to the learners. It is leading to the evolution of new concepts and innovative teaching techniques in the instructionlearning process. It is changing the way teachers teach and students learn. As stated by Bates (2000),

...modern education theory is moving beyond the recall of facts, principles, or correct procedures and into the areas of creativity, problem-solving, analysis, or evaluation (the very skills needed in the workplace in a

knowledge-based economy, not to mention in life in general). Learners need the opportunity to communicate with one another as well as with their

teachers. This of course includes the opportunity to question, challenge and discuss issues. Learning is as much a social as an individual activity.

This changing landscape of education focusses on the learner, rather than on teaching and pedagogy, curriculum and instruction. It seeks to create a generation of learners whose learning is defined as "the ability to retain, synthesize, and apply conceptually complex information in meaningful ways" (Lambert \& McCombs, 1998), and to encourage better student learning through the learning objectives of project based learning or learning by doing (Schank, Berman \& Macpherson, 1999). In addition to this, multimedia technology has been shown to affect students' motivation and self esteem levels, as well as allow them to be creative and self directed thinkers (Agnew, Kellerman \& Meyer, 1996).

What is a constructivist learning environment? Wilson (1995) defined it as "a place where learners may work together and support each other as they use a variety of tools and information resources in their pursuit of learning goals and problem-solving activities." As stated by Savery and Duffy (1995), the learning activities generated by solving a design oriented problem are constructivist in approach. This mode of learning is considered as a student centred instructional model whereby students determine their own learning needs, set their own goals, monitor their own progress and determine how to reach the desired learning outcomes in a 
collaborative learning environment (Land \& Hanafin, 1996; Newby, Stephich, Lehman \& Russell, 2000; Yildirim, 2005). The teacher is no longer perceived as the sole authority, but rather as the facilitator of learning, guiding and supporting learners in the process of constructing knowledge (Berge, 1999; Nelson, 1999). The amount of guidance teachers provide depends on students' prior knowledge levels and experiences (Orlich, Harder, Callahan \& Gibson, 1998; Vygotsky, 1978).

This constructivist process is geared towards determining how the student structures and processes knowledge rather than how much is learned (Mayer, 1998). Thus, the focus is on the learning process rather than on the content, learning 'how to learn' rather than 'how much is learned'. Students develop critical thinking skills, problem solving and team skills, experiential learning and interdisciplinary knowledge, with technology being integral to their learning (Cook \& Cook, 1998; Oliver, 2000). It also represents a move away from traditional education towards learners being active participants in the learning process (Oliver, 1998).

In constructivism, there is a strong belief that learning is a personal interpretation of the world, as learners create interpretations of the world based on their past experience and interpretations (Wilson, 1995; Duffy \& Cunningham, 1996; Jonassen \& Henning, 1999). In this context, students must play an active part in their learning process and not remain as passive learners as in the teacher led instruction process whereby the teacher is the sole authority and distributor of knowledge. In the constructivist mode of learning, the learning process is shifted towards the student centred mode where students become active learners and take more responsibility for their own learning, and in the process, learn to construct knowledge on their own and determine their own learning outcomes. Collaboration is an important and integral component to the learning process, whereby the learner seeks out more experienced people to help solve the task and in doing so, acquires knowledge and experience he or she would not otherwise have had if acting individually. Scaffolding, then, becomes an important aspect to constructivist learning as older, more experienced peers, as well as teachers, become "scaffolds" who help and support individual learners in a task and guide them until they reach a sufficient competence level (Winnips \& McLoughlin, 2001; McLoughlin, 1999; Collis, Winnips \& Moonen, 2000). The collaborative activities with others allow them to develop multiple perspectives, where some type of "shared reality" is produced (Jonassen, 2000) and enables them to consider "...varying and discrepant points of view with which to consider the merits of his or her own mental models" (Oliver, 2000).

The advantages of constructivism are that it provides learner centred activities in the learning process, enables students to participate in their 
learning process and become autonomous and independent while the teacher acts as a facilitator, supporting the students in their learning process, facilitating social interactions and communications between students, and encouraging collaborative and cooperative learning. In such an activity, student centred learning can be cultivated because the students will engage in collaborative activities with their team members, as well as with the instructor, who acts as a facilitator and guide to the students. By working in a group situation, students will have to tap into their group skills and use a variety of activities to accomplish the project's overall objectives. The group would be responsible for their goals and learn to solve problems and work collaboratively. Learning takes place in a meaningful, authentic context and is a social, collaborative activity, where peers play an important role in encouraging learning (Herrington, Oliver, Reeves \& Woo, 2004).

\section{Multimedia and constructivist learning in Malaysia}

In Malaysia, the Government is echoing this learner centred learning initiative and has thereby called for using multimedia materials for student development, self assessment and self directed learning (Mohaiadin, 2000; Chee, 2000) as well as e-learning methods in the universities (Kamsah, Mokhtar, Ahmad \& Yaacob, 2000; Ismail, 2001). There is a strong initiative in the country to integrate technology and multimedia into the classrooms and to encourage educators in institutions of higher education to integrate the existing curricula into technology based, learner centred programs where students become active participators in their learning process, and become developers of multimedia applications (Mat 2000; Moggie, 2000). Institutions of higher learning here in Malaysia are thus meeting these challenges by integrating multimedia into various teaching and learning environments such as storytelling (Norhayati \& Siew, 2004), problem based learning (Neo \& Neo, 2001, 2005; Hong, Lai \& Holton, 2003), web based courses (Rohaida \& Kamariah, 2000; Hong, Abang Ekhsan \& Zaimuarifuddin, 2005; Neo, 2005), and in e-learning applications (Lee, 2005; Suraya, 2005).

Much of this push to incorporate constructivist based approaches into teaching and learning is in answer to the problem of current graduates lacking in creativity, communications skills, and analytical, critical thinking, and problem solving skills (Teo \& Wong, 2000; Siaw, 2000: Tan, 2000). This mismatch has created a need to seek new ways to transfer the appropriate skills and knowledge to the students in order to meet the rising expectations of the IT society. Research in Malaysia has shown that using constructivism and multimedia technology are becoming increasingly important in teaching and learning in higher education in order to promote and enhance the teaching and learning process. Shaziti 
(2000) posited an online learning environment as a platform to support constructivist teaching and learning practices in the everyday classroom, to provide "a repository of useful resources, to showcase teacher 'best practices' and for reflective dialogue." Lee (1999) reported on the Malaysian experience with students in a joint collaboration study on the use of problem solving methods in a constructivist environment with learners from three different countries, and found that rich learning environments must present authentic problems to the learners. Lee (2005) found that constructivist approaches such as guided discovery, interactive Q\&A sessions and the use of multimedia elements such as animations, simulations and graphics enabled mathematics students to learn better, by promoting active learning strategies in distance and e-learning environments. Wong, Kamariah and Tang (2003) investigated the use of a constructivist learning environment for addressing anxiety levels among pre-service teachers, and found that it was successful in reducing the anxiety levels among participants who perceived themselves as IT incompetent, enabling them to better transfer their knowledge to their students in the classrooms.

Therefore, in their efforts to progress towards more student centred methods of teaching and learning, Malaysian institutions of higher education need to further study the use of constructivism and multimedia technology. In this case study, we sought to provide an alternative method to enhance the student learning process in the constructive perspective through the development of a multimedia project embedded in a constructivist learning environment and to study its impact on the learning process of Malaysian students. By integrating a multimedia project into a constructivist learning environment, students would have to apply the Multimedia Development Process (MDP) in order to complete it. Throughout this process, students have to actively participate in their own learning process and become more engaged learners. This study reports on the students' feedback and their experience with collaborative problem solving.

\section{Methodology}

The study was coducted with 53 second year students $(\mathrm{N}=53)$ from 3 different faculties, the Faculty of Management, the Faculty of Information Technology and the Faculty of Engineering, who were enrolled in the Interactive Multimedia course (or unit). The objective for this course was to acquire multimedia development skills through the creation of an interactive group application authored in Macromedia Director. The course was 14-weeks long and consisted of lectures, laboratory tutorials and consultations. The project was focussed around an authentic setting context (Herrington, Oliver, Reeves \& Woo, 2004), with the project theme Malaysian 
culture. Here students developed prototype applications on any aspect of Malaysian culture for the Malaysian Tourism Board. Students worked in groups to design, develop and implement their concept for the application and would be responsible for all the decisions made in this process. The authoring tool used to create the final application was Macromedia Director, although students were free to use any third party software to enhance their final Director application (Tai, Neo \& Teoh, 2005).

\section{Developing the constructivist based environment}

Constructivist environments are designed so that students will be able to become active participants in their learning process and develop skills that would allow them to think critically, function well as a member of a team, develop collaborative abilities and deepen their understanding of their task. Jonassen (1999) also proposes that an essential part of the problem is that it has to be interesting, engaging and appealing. It must also be authentic, personally relevant, challenging and interesting to learners, and provide a physical simulation of the real world task environment. As such, these components were adapted into the design of this study to create an effective constructivist learning environment for the Malaysian classroom. In this project, the students engaged in the Multimedia Development Process (MDP) (Neo \& Neo 2004; Luther, 1994). The MDP is a development method which outlines students' process from the ideation of the project in the beginning, to its implementation using the authoring tool, Macromedia Director, to the delivery of the final application. The MDP involves 3 phases, depicted schematically in Figure 1.

\section{The pre-authoring phase}

The pre-authoring phase involves the planning of the project. The plan identifies the specific aspect of the project that the student groups want to present, the overall concept of their project or solution, and the target audience. It groups brainstorming activities and storyboarding of ideas. It also involves the acquisition of media elements (text, graphics, animation, sound and video) from various analogue or digital sources. Media elements acquired from analogue sources are converted into digital formats and saved in the computer for later use. In this phase, students can also edit and modify their media using third party software such as Adobe Photoshop (for image files), Premier (for video files), Flash (for animation files), and SoundForge (for sound files), to customise them to their project's design.

\section{The authoring phase}

This is characterised by the integration and synchronisation of media elements in an authoring tool and the integration of interactivity, to create one final, standalone application. Interfaces designed according to the 
storyboard in the pre-authoring phase are used in the application, and the media elements are incorporated accordingly. Interactive features and navigational tools are incorporated, and the final application is then packaged, or saved, as a standalone application for delivery to the end user.

3. The post-authoring phase

The final application is presented and delivered to the end user. It is interactive, media rich, and is presented in accordance with the group's own concept of what the project should be, as decided by the group in the pre-authoring phase.

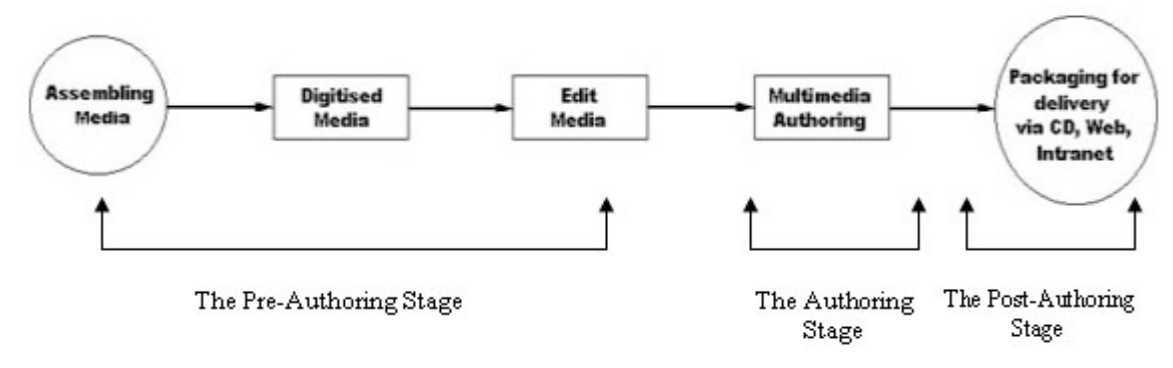

Figure 1: The Multimedia Development Process (MDP)

(Neo \& Neo, 2004)

\section{The student's collaborative problem solving learning process}

Students followed a six step problem solving learning process, including the MDP, which outlined a learning strategy for the multimedia project development. Students worked collaboratively in groups to achieve solutions to their common problem. The learning process, depicted schematically in Figure 2, is defined as follows.

\section{Group formation and task delegation}

Students began their collaboration by forming groups of 4 to 5 members and choosing a group leader. At this stage, groups created their own group identity and began division of tasks.

\section{Collaboration}

Collaboration in the project took the form of brainstorming activities to identify a variety of possible solutions to their project problem, as well as the skills needed in the group to properly develop the application. Students scoured the Internet for ideas and resources to help them make decisions and group meetings were held to discuss these issues. Ideas for the project were then presented as a proposal to the class and the lecturer, who was acting as a facilitator in the class, for feedback and approval. 
3. Pre-authoring: Conceptualisation

Storyboarding and interface design were carried out in this stage, where student groups visualised and generated materials for the final application. Members created sketches for the interfaces of their application's screen and started to acquire the necessary media elements (e.g. graphics, sound, video, animation and text) and created the visuals for their Director application. This process was iterative as members modified their designs according to ongoing group discussions and decisions. Conflict management and problem solving were prevalent in this stage as members experienced problems in group dynamics.

4. Authoring: Integration and interactivity

In this stage, student groups utilised Macromedia Director to translate their storyboard concepts to the final digital application. Collaboration was still prevalent in this stage as students collaborated to put their individual screens together under one final application.

\section{Post-authoring: Presentations}

Work in progress presentations were carried out to ensure groups were progressing on schedule and to solicit feedback and comments from other members in the class. Final presentations, two weeks later, were done to showcase the completed application.

\section{Reflective thinking}

Reflective thinking occurred throughout the development period and encouraged students to think about their progress in the class, the problems they faced and how they overcame them. Reflective thoughts were documented in their journal reports at the end of the semester.

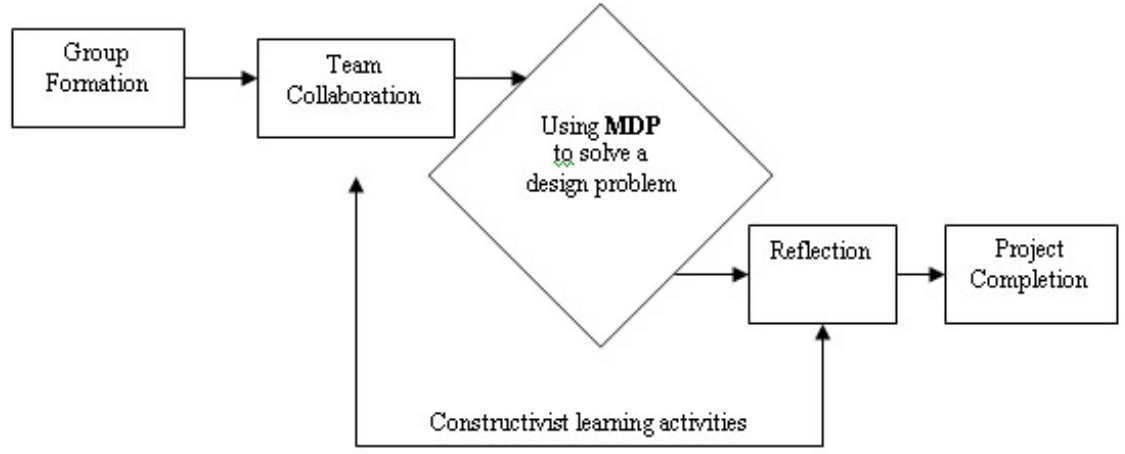

Figure 2: The students' collaborative problem solving learning process

Throughout their learning, aside from the face to face meetings, students utilised various methods of communication and collaboration tools, 
especially the Yahoo! Instant Messenging service, emails and even telephone SMS (short messaging service) to exchange ideas and files, collaborate, hold meetings and discussions, and keep in touch with each other.

Table 1: Means and percentages on the student survey $(\mathrm{N}=53)$

\begin{tabular}{|c|c|c|c|c|c|c|c|c|}
\hline No & Items & $\begin{array}{l}\text { Mean } \\
(\mathrm{m})\end{array}$ & $\begin{array}{l}\%(\mathrm{p}) \\
\text { SA }\end{array}$ & $\begin{array}{c}\%(\mathrm{p}) \\
\mathrm{A}\end{array}$ & $\begin{array}{l}\%(\mathrm{p}) \\
\mathrm{U}\end{array}$ & $\begin{array}{l}\%(p) \\
D\end{array}$ & $\begin{array}{l}\%(p) \\
\text { SD }\end{array}$ & $\begin{array}{l}\text { Std. } \\
\text { dev. }\end{array}$ \\
\hline 1. & $\begin{array}{l}\text { Challenging yet inspiring } \\
\text { project }\end{array}$ & 4.2 & 24.5 & 67.9 & 5.7 & 1.9 & 0 & 0.60 \\
\hline 2. & $\begin{array}{l}\text { I felt motivated to involve } \\
\text { myself in project }\end{array}$ & 4.0 & 18.9 & 64.2 & 15.1 & 0 & 1.9 & 0.72 \\
\hline 3. & $\begin{array}{l}\text { Willing to change to keep } \\
\text { growing }\end{array}$ & 4.2 & 24.5 & 66.0 & 9.4 & 0 & 0 & 0.57 \\
\hline 4. & $\begin{array}{l}\text { Accept critical/negative } \\
\text { comments }\end{array}$ & 4.1 & 24.5 & 62.3 & 9.4 & 3.8 & 0 & 0.70 \\
\hline 5. & $\begin{array}{l}\text { Place more emphasis on } \\
\text { learning in the project than } \\
\text { studying for exams }\end{array}$ & 3.9 & 22.6 & 50.9 & 24.5 & 0 & 0 & 0.74 \\
\hline 6. & $\begin{array}{l}\text { The individual and group } \\
\text { assessments encourage me to } \\
\text { give full commitment }\end{array}$ & 3.8 & 7.5 & 66.0 & 22.6 & 3.8 & 0 & 0.64 \\
\hline 7. & $\begin{array}{l}\text { Smooth interactions tightened } \\
\text { the bond among members }\end{array}$ & 3.7 & 17.0 & 45.3 & 30.2 & 3.8 & 3.8 & 0.94 \\
\hline 8. & $\begin{array}{l}\text { Willing to pay price to ensure } \\
\text { growth of group }\end{array}$ & 3.9 & 15.1 & 58.5 & 24.5 & 1.9 & 0 & 0.68 \\
\hline 9. & $\begin{array}{l}\text { Able to manage group } \\
\text { effectively }\end{array}$ & 3.6 & 7.5 & 54.7 & 30.2 & 5.7 & 1.9 & 0.79 \\
\hline 10. & $\begin{array}{l}\text { Willing to make improvements } \\
\text { to keep project growing. }\end{array}$ & 4.0 & 20.8 & 56.6 & 20.8 & 1.9 & 0 & 0.57 \\
\hline 11. & $\begin{array}{l}\text { Team resolve problems } \\
\text { together }\end{array}$ & 3.9 & 22.6 & 56.6 & 13.2 & 7.5 & 0 & 0.73 \\
\hline 12. & $\begin{array}{l}\text { Team solve problems in } \\
\text { positive manner }\end{array}$ & 4.0 & 18.9 & 64.2 & 11.3 & 5.7 & 0 & 0.82 \\
\hline 13. & $\begin{array}{l}\text { Project presented well using } \\
\text { MM technology }\end{array}$ & 3.6 & 11.3 & 47.2 & 30.2 & 9.4 & 1.9 & 0.89 \\
\hline 14. & $\begin{array}{l}\text { Presentation skills developed } \\
\text { and improved }\end{array}$ & 3.6 & 11.3 & 45.3 & 35.8 & 7.5 & 0 & 0.79 \\
\hline 15. & $\begin{array}{l}\text { Project increased my } \\
\text { understanding }\end{array}$ & 4.1 & 18.9 & 71.7 & 7.5 & 1.9 & 0 & 0.58 \\
\hline 16. & Capable of thinking critically & 4.0 & 17.0 & 64.2 & 18.9 & 0 & 0 & 0.60 \\
\hline 17. & $\begin{array}{l}\text { Gained confidence in acquired } \\
\text { skills }\end{array}$ & 3.9 & 17.0 & 66.0 & 11.3 & 5.7 & 0 & 0.72 \\
\hline 18. & $\begin{array}{l}\text { Developed skills needed in } \\
\text { real-world }\end{array}$ & 3.9 & 15.1 & 64.2 & 18.9 & 1.9 & 0 & 0.65 \\
\hline 19. & Able to apply skills & 4.1 & 22.6 & 64.2 & 13.2 & 0 & 0 & 0.71 \\
\hline 20. & $\begin{array}{l}\text { Overall, I am very satisfied } \\
\text { with my performance }\end{array}$ & 3.8 & 18.9 & 50.9 & 26.4 & 1.9 & 1.93 & 0.83 \\
\hline
\end{tabular}




\section{Results: Student surveys, comments and interviews}

Students were given a 20-item questionnaire adapted from Neo and Neo (2001) and Diamond (1998). This survey was structured to measure individual, group and project performances. It used a 5 point Likert Scale from Strongly disagree $(\mathrm{SD}=1)$, Disagree $(\mathrm{D}=2)$, Undecided $(\mathrm{U}=3)$, Agree $(\mathrm{A}=4)$ to Strongly agree $(\mathrm{SA}=5)$. The sample size was 53 students $(\mathrm{N}=53)$. The students were required to fill up the survey at the end of the project development period to reflect on their learning and performances after the project experience. The data were analysed using SPSS (Statistical Package for Social Sciences), and yielded a Cronbach Alpha coefficient of 0.8 , which satisfied the requirement for survey reliability (Lim, Khine, Hew, Wong, Shanti \& Lim, 2003). Table 1 presents the results.

The survey also sought open ended comments from students to elicit more in depth feedback on their attitudes towards the project. These open ended comments were at the end of the survey and students were encouraged to be candid and honest with their feedback. These comments were useful to gauge the individual student's inner feelings toward the development of the multimedia project and working in a team to complete it. These comments, illustrated in Table 2, also provide richer support for the survey items that the students' completed at the same time.

Results in Table 1 show that the majority means were above 3.6, indicating very favourable and positive responses from the students in this learning environment. Comments in Table 2 lent further support to the results in Table 1 as students provided richer and more candid comments to the items on the survey. All of the responses in the three tables were organised and reported together (concurrently) under the four constructs detailed below.

\section{Motivation}

This construct sought to measure the students' motivation towards developing a multimedia project as part of their learning process, and was made up of Items 1, 2, 13, 17 and 20 on the survey. Overwhelmingly, 92.5\% of students in the class reported that the project was challenging yet inspiring (Item 1, $\mathrm{m}=4.2$ ), making that item the highest rated item in the survey. This is followed by $83 \%$ of students reporting that they felt motivated to be involved in project (Item 2, m=4) and that the project was presented very well using multimedia technology (Item 13, $\mathrm{m}=3.6$, $\mathrm{p}=58.5 \%$ ). $83 \%$ of students also reported that they gained confidence in their acquired skills after completing the project (Item 17, $\mathrm{m}=3.9$ ), and $69.8 \%$ reported being very satisfied with their performance (Item 20, $\mathrm{m}=3.8$ ). The survey results are further supported by the comments at the end of the survey, as shown in Table 2. Results showed that learners were 
delighted and satisfied with knowledge achievement through the learning activity, for example comments 1 and 2 in Table 2

Table 2: Student's comments and feedback on the survey

Motivation

1. "I feel very happy and satisfied with the result. It made me feel everything is worth it. But, I guess there are a lot more to learn"

2. "I feel excited and happy for the successful completion of the project. I'm thankful also that all our hard work paid off."

3, "Yes, very much! This project is new to us, very experimental and fun. We are very excited."

4. "I feel satisfied and proud that our application came out great and this feeling encourages me to create more better applications in the future."

Knowledge construction/enhancement

5. "I feel that I had gain more knowledge and experience by doing the group assignments."

6. "I feel the course is very useful and interesting for me to apply in my future."

7. "In class, we only study the theories. But in this project, we get lots of hands on practices, hence understand the whole idea, and we can develop something together."

8. "This project makes us force ourselves to learn and apply. We think that it is good."

Teamwork and collaboration

9. "I feel really glad to be in this group as we work together very well and my team mates really help each other when we have problems."

10. "I feel interesting in this course because I can know other faculty friends and share the knowledge that I did not learn from my major such as, programming or scripting."

11. "We prefer working in team because we can share a lot of ideas from the members."

Skills

12. "I had improved my multimedia skills from this project."

13. "...in this project, we really learnt what we want to achieve and really try our way to do it... We've make use of the theories we've learnt in class into this assignment."

14. "Pretty much confident about doing all those application in the future because ...We already know the step... So in the future we can refer or recall, back to our project then how we solve the problem, so it helps us."

2. Knowledge construction/enhancement

This construct measured the students' perception of their knowledge construction process and their attitudes towards an increased understanding of the topic after the project was completed and were made up of Items 3, 4, 5, 6 and 15 on the survey. As seen in Table 1, the survey showed that $90.6 \%$ of students reported that the project increased their understanding of managing and developing a multimedia application (Item 15, $\mathrm{m}=4.1$ ). 90.6\% of the students also reported that they were willing to change to keep growing, even if it meant sacrificing a lot of time learning 
to solve problems by themselves (Item 3, $\mathrm{m}=4.2$ ). $86.8 \%$ of students reported a willingness to get rid of improper attitudes and inappropriate methods in acquiring knowledge by being open to critical or negative comments (Item 4, m=4.1). They also reported favorably upon the individual and group assessments, which they found encouraged them to give full their commitment to the project (Item 6, $\mathrm{m}=3.8, \mathrm{p}=73.6 \%$ ). $73.6 \%$ of students reported that they placed more emphasis on learning by doing the project instead of just studying for exams (Item 5, m=3.9), which allowed them to understand their topic and the class better. Results from their comments also lent support to the notion that the project enabled them to build knowledge and increase their understanding, for example comments 6 and 7 in Table 2.

\section{Teamwork/collaboration}

In the teamwork/collaboration construct, students were measured on their willingness to participate as team members and support the team goals and were made up of Items 7, 8, 9, 10, 11 and 12 on the survey. Results showed that students were very positive towards working in teams. As seen in Table 1, 77.4\% of students reported favourably on their willingness to make improvements to keep project growing (Item 10, $\mathrm{m}=4.0$ ). $73.6 \%$ of students reported that they were willing to pay price to ensure growth of group (Item $8, \mathrm{~m}=3.9$ ), which reflected their concern towards learning and team building. In terms of solving problems, $79.2 \%$ of students reported that the team resolved their group problems together (Item 11, $\mathrm{m}=3.9$ ) and in positive manner (Item 12, $\mathrm{m}=4, \mathrm{p}=83 \%$ ). The majority of them reported being able to manage team work effectively (Item 9, $\mathrm{m}=3.6, \mathrm{p}=62.3 \%$ ), with $62.3 \%$ reporting that the smooth interactions tightened the bond among members (Item 7, $\mathrm{m}=3.7$ ). Comments from students in Table 2 also showed that teamwork was an integral part to the successful completion of the project. Some found the benefits of teamwork as they are able to learn more knowledge than expected, for example comments 9 and 10.

4. Skills (critical thinking, problem solving, confidence and presentation skills)

This construct sought to measure students' attitudes toward the various skills experienced during the project development period and were made up of Items 14, 16, 18 and 19 on the survey. As seen in Table 1, 81.1\% of students reported that the project allowed them to think critically (Item 16, $\mathrm{m}=4.0), 56.5 \%$ of students reported that the project allowed them to develop and improve their presentation skills (Item 14, $\mathrm{m}=3.6$ ). Many realised that they had developed skills needed in the real world (Item 18, $\mathrm{m}=3.9, \mathrm{p}=79.2 \%$ ), with $86.8 \%$ of students reporting that they were now able to apply these skills in a more valuable manner on upcoming projects (Item $19, \mathrm{~m}=4.1)$. They also reported similar attitudes in their comments on the survey, for example 12 and 13 in Table 2. 
To provide further support to the survey and feedback results, students' learning outcomes in the form of their final project are showcased in Figures 3 and 4 . These examples of their work are in line with Winnips \& McLoughlin's (2001) statement that student' final learning outcomes show proof of student learning. Figure 3 shows a screen picture from one group's interactive application on Malaysian heritage, Baba \& Nyonya, and Figure 4 is a screen picture from another group's interactive application on Malaysian traditional craft, Wayang Kulit (shadow puppets).

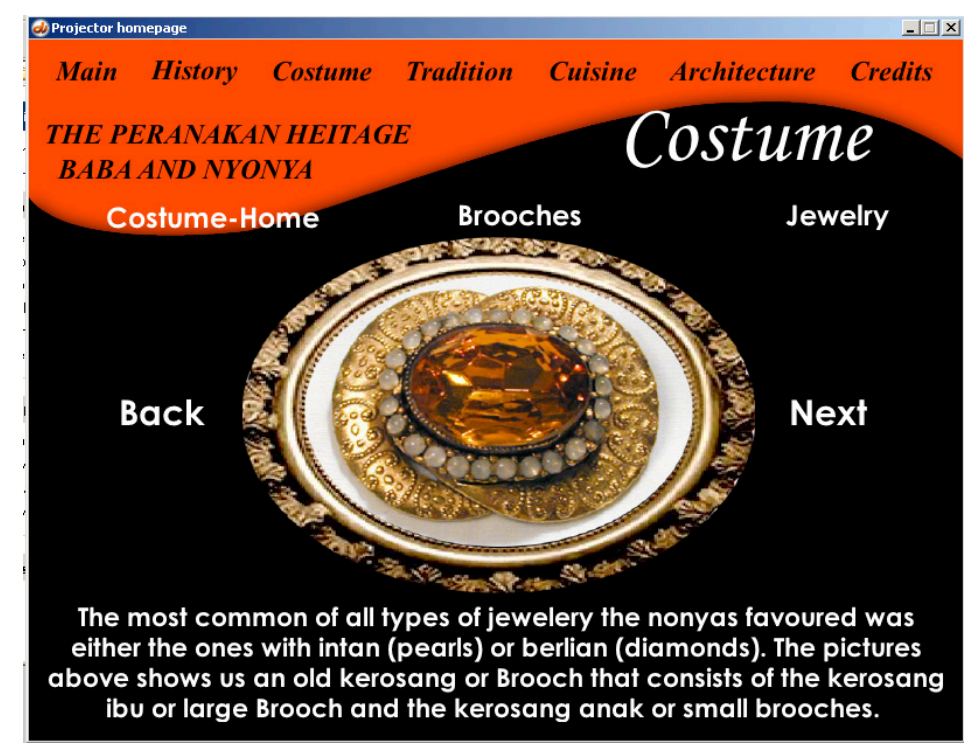

Figure 3: An interface from one group's application on Malaysian heritage

\section{Discussion: Students' perceptions on learning}

From this study, it is quite clear that the constructivist learning environment had an important influence on these Malaysian students' learning process. By allowing students the creativity and responsibility to create and develop an interactive multimedia project via an authentic theme, based on their group's decision making process, they were able to harness several salient constructivist attributes which enabled them to be more active in their learning process. In particular, the authors found that:

1. The incorporation of the multimedia development process (MDP) within this constructivist based learning environment enabled students to engage in many constructivist learning activities, Through the MDP, they engaged in research, planning and organising of the content of the 


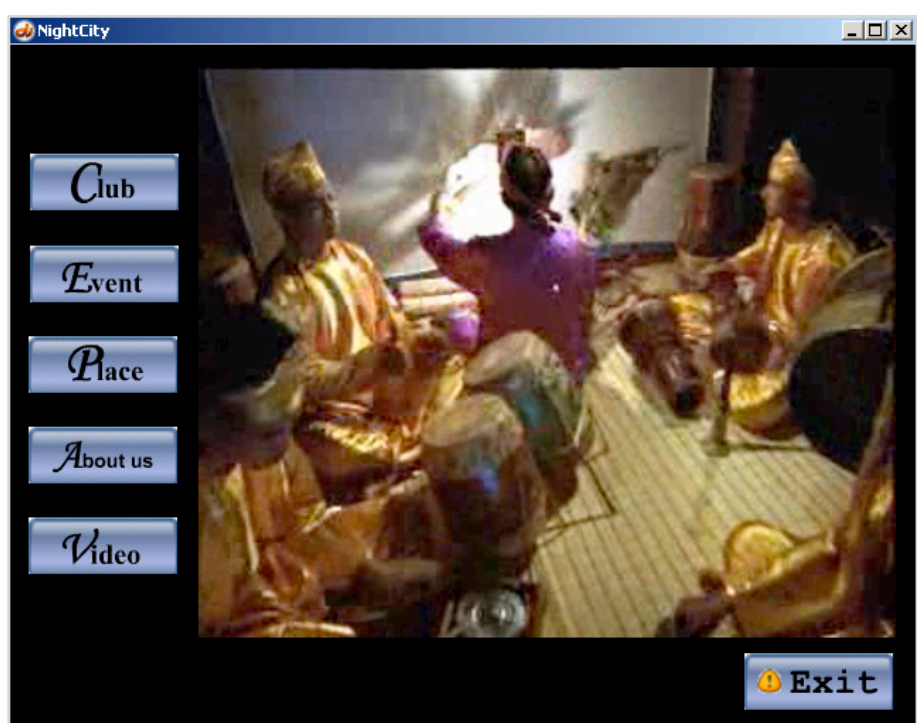

Figure 4: An interface of one group's application on Malaysian traditional craft, Wayang Kulit (shadow puppets)

project and structure solutions to the problems as per their own group's learning path. They were able to design and create multiple solutions or multiple expressions to the same problem, as they are able to incorporate their experiences and their own views of the world to make it meaningful to them.

2. Students were very motivated to finish the project and see their final results. This is indicative in their survey results, their open ended comments, as well as in their interviews. Even though they did find that the project was challenging at times, they were still able to report enjoying their work and feeling confident in their multimedia development capabilities.

3. The incorporation of a multimedia project allowed students to become multimedia designers and exercise their creativity in using various combinations of multimedia elements in the project design. Thus, this multimedia mediated, constructivist based learning environment allowed students to gain increased understanding of their work and their project topic. By designing an authentic learning environment where students had an active interest in the outcome of the task at hand, they were more apt to pay attention to the information presented, and in doing so, enhanced their understanding of multimedia as well as their topic, making them more likely to become lifelong learners. 
Multimedia technology became an enabler for them to become actively involved in their learning process and experience high motivation levels.

4. This learning environment also encouraged and supported collaborative peer learning, where the teacher acted as a facilitator and consultant, guiding students in solving their problems. Students were able to work together to make decisions, and implement them as a group, in order to complete their group task, despite several obstacles such as scheduling conflicts, lack of skills and personality conflicts.

5. They were also able to display metacognitive skills, which Bentham (2002, p114) defined as the "personal awareness of factors that influence... thinking, learning and problem-solving abilities". This is indicative of students' ability to see the relevance of their project to real life work situations. From their comments and interviews, students did not view the project simply as a classroom exercise, but rather as an experience acquired for real life situations. This showed that the project was successful in bridging the gap between students' theoretical understanding of interactive multimedia and its practical uses in the real world, and has important implications for their future.

This investigation shows that using a multimedia project within a constructivist based learning environment can be successful in effecting salient constructivist attributes such as problem solving and critical thinking skills, creativity, presentation and reflection skills, resulting in enhanced knowledge construction and increased motivation levels. The incorporation of computer and multimedia technologies into such a learning environment serves to further strengthen their involvement and commitment and make them more active participants in their learning process. The results of the study showed that this alternative method provided Malaysian students the opportunity to enhance their learning process and improve their understanding of the subject matter and thus provide further positive encouragement towards the development of constructivist learning environments as well as innovative teaching and learning methods using multimedia and digital technologies in Malaysian classrooms.

\section{Acknowledgements}

The research was funded by a Multimedia University Internal Funding grant. The authors wish to thank the students in the Interactive Multimedia class, Multimedia University, Malaysia, for their cooperation in this research project, and the Multimedia University for the facilities and support. 


\section{References}

Agnew, P. W., Kellerman, A. S. \& Meyer, J. (1996). Multimedia in the classroom. Allyn and Bacon, Boston.

Bates, A. W. (2000). Managing technological change. Jossey-Bass: San Francisco.

Bates, A. W. \& Poole, G. (2003). Introductory remarks on knowledge, learning and teaching. In Effective teaching with technology in higher education. San Francisco: Jossey-Bass.

Bentham, S. (2002). Psychology and education. New York: Routledge.

Berge, Z. L. (1999). Interaction in post-secondary web-based learning. Educational Technology, January/ February, 5-11.

Chee, K. Y. T. (2000). Running a Smart School successfully. e-learning 2000: Accelerating e-Learning Towards Higher Education Value, Malaysian International Conference E Exhibition on Electronic Learning 2000, Kuala Lumpur, Malaysia.

Collis, B. A., Winnips, K. \& Moonen, J. (2000). Structured support versus learner choice via the World Wide Web (WWW): Where is the payoff? Journal of Interactive Learning Research, 11(2), 131-162.

Cook, J. \& Cook, L. (1998). How technology enhances the quality of student-centred learning. Quality Progress, 31(7).

Diamond, R. M. (1998). Designing \& assessing courses $\mathcal{E}$ curricula -- A practical guide. San Francisco: Jossey Bass.

Duffy, T. M. \& Cunningham, D. J. (1996). Constructivism: Implications for the design and delivery of instruction. In D. H. Jonassen (Ed.), Handbook of research for educational communication \& technology. NY: Simon \& Schuster Macmillan.

Herrington, J., Reeves, T. C., Oliver, R. \& Woo, Y. (2004). Designing authentic activities in web-based courses. Journal of Computing and Higher Education, 16(1), 3-29.

Hong, K. S., Lai, K. W. \& Holton, D. (2003). Students' satisfaction and perceived learning with a web-based course. Educational Technology \& Society, 6(1), 116-124. http: / / www.ifets.info/ others / download_pdf.php?j_id=7\&a_id=130

Hong, K. S., Abang Ekhsan, A. O. \& Zaimuarifuddin, N. (2005). Computer selfefficacy, computer anxiety, and attitudes towards the Internet: A study among undergraduates in Unimas. Educational Technology E Society, 8(4), 205-219. http: / / www.ifets.info/others / download_pdf.php?j_id=29\&a_id=590

Jonassen, D. H. (1999). Designing constructivist learning environments. In C. M. Reigeluth (Ed.), Instructional theories and models: A new paradigm of instructional theory (2nd edition), pp. 215-239. Mahwah, NJ: Lawrence Erlbaum.

Ismail, Z. (2001). Learning for the knowledge society: National E-Learning Agenda (NELA). National Conference \& Exhibition on Electronic Learning 2001 (e-learning 2001): Moving Towards e-Learning Society, 7-8 June, Petaling Jaya, Malaysia.

Jonassen, D. H. (2000). Computers as mindtools for schools: Engaging critical thinking. NJ: Merrill. 
Jonassen, D. H. \& Henning, P. (1999). Mental models: Knowledge in the head and knowledge in the world. Educational Technology, 39(3), 37-42.

Kamsah, M., Mokhtar, S., Ahmad, R. \& Yaacob, M. (2000). Developing the concept of e-university for Malaysian public universities. e-learning 2000: Accelerating eLearning Towards Higher Education Value, Malaysian International Conference $\mathcal{E}$ Exhibition on Electronic Learning 2000, Kuala Lumpur, Malaysia.

Lambert, N. M. \& McCombs, B. J. (1998). Introduction: Learner-centered schools and classrooms as a direction for school reform. In N. M. Lambert \& B. L. McCombs (Eds.), How students learn: Reforming schools through learner-centered education, pp. 1-22. Washington, DC: American Psychological Association.

Land, S. M. \& Hannafin, M. J. (1996). Student-centred learning environments: Foundations, assumptions and implications. In Proceedings of Selected Research and Development Presentations at the 1996 National Convention of the Association for Educational Communications and Technology, Indianapolis: IN. pp. 395-400.

Lee, C. S. (1999). Problem-solving in a constructivist environment. Educational Technology E Society, 2(4), 137-145. http: / / www.ifets.info / others / download_pdf.php?j_id=20\&a_id=461

Lee Y. L (2005). Integrating constructivist approaches in e-learning to enhance mathematical self-study. The Mathematics Education into the 21st Century Project, Universiti Teknologi Malaysia: Reform, Revolution and Paradigm Shifts in Mathematics Education. Johor Bahru, Malaysia, 25 Nov - 1 Dec. http: / / math.unipa.it/ grim/21_project/21_malasya_ZLee\%20Ya\%20Ling238242_05.pdf

Lim, C. P., Khine, M. S., Hew, T., Wong, P., Shanti, D. \& Lim, B. (2003). Exploring critical aspects of information technologies integration in Singapore schools. Australian Journal of Educational Technology, 19(1), 1-24. http: / / www.ascilite.org.au/ajet/ ajet19/lim.html

Lindstrom, R. (1994). The Business Week guide to multimedia presentations: Create dynamic presentations that inspire. McGraw-Hill, New York.

Luther, A. C. (1994). Authoring interactive multimedia. MA: AP Professional.

Mat, J. (2000), Technology in the Malaysian Education System. Opening address at the E-Learning conference, 25 May, Kuala Lumpur, Malaysia.

Mayer, R. E. (1998). Cognitive theory for education: What teachers need to know. In N. M. Lambert \& B. L. McCombs (Eds), How students learn: reforming schools through learner-centered education, pp. 353-377. American Psychological Association, Washington DC.

McLoughlin, C. (1999). Scaffolding: Application to learning technology supported environments. In B. Collis \& R. Oliver (Eds.), Proceedings of EdMedia 1999: World Conference on Educational Multimedia and Hypermedia, pp. 1827-1832. Charlottesville, VA: AACE.

Moggie L. (2000). Opening speech by Datuk Amar Leo Moggie, Minister of Energy, Communications and Multimedia. In Proceedings of the International Conference: Education E ICT in the New Millenium. Kuala Lumpur, Malaysia, 27 October, pp. iii-x. 
Mohaiadin, J. D. (2000). Information technology/MSC: Who benefits most? In Proceedings of the International Conference: Education E ICT in the New Millenium, Kuala Lumpur, Malaysia, 1-14.

Nelson, L. M. (1999). Collaborative problem solving. In C. M. Reigeluth (Ed.), Instructional theories and models: A new paradigm of instructional theory (2nd edition) Mahwah, NJ: Lawrence Erlbaum, pp. 161-181.

Neo, M. (2005). Web-enhanced learning: Engaging students in constructivist learning. Campus-Wide Information Systems, 22(1), 4-14.

Neo, M. \& Neo, T. K. (2001). Innovative teaching using multimedia in a problembased learning environment. Educational Technology \& Society, 4(4), 19-31. http: / / www.ifets.info/others / download_pdf.php?j_id=12\&a_id=166

Neo, T. K. \& Neo, M. (2004). Classroom innovation: Engaging students in interactive multimedia learning. The Campus-wide Information Systems (CWIS): The International Journal of Technology on Campus, 21(3).

Neo, M. \& Neo, T. K. K. (2005). A multimedia-enhanced problem-based learning experience in the Malaysian classroom. Learning, Media \& Technology, 30(1), 41-53.

Norhayati, A. M. \& Siew, P. H. (2004). Malaysian perspective: Designing interactive multimedia learning environment for moral values education. Educational Technology \& Society, 7(4), 143-152.

http: / / www.ifets.info/others / download_pdf.php?j_id=25\&a_id=499

Newby, T. J., Stepich, D. A., Lehman, J., D. \& Russell, J. D. (2000). Instructional technology for teaching and learning: Designing instruction, integrating computers, and using media (2nd Ed). Merrill/ Prentice Hall, New Jersey.

Oliver, K. M. (2000). Methods for developing constructivist learning on the web. Educational Technology, November-December, 5-18.

Oliver, R. (1998). Partnerships in teaching and learning: An emerging role for technology. Proceedings of EdTech'98: The Biennial Conference of the Australian Society for Educational Technology. Perth: ASET. http:/ / www.ascilite.org.au/asetarchives / confs/edtech98/pubs/articles/oliver.html

Orlich, D. C., Harder, R. J., Callahan, R.C. \& Gibson, H.W. (1998). Teaching strategies: A guide to better instruction. New York: Houghton Mifflin.

Rohaida, M. S. \& Kamariah, A. B. (2000). A development of a web-based instruction for primary school: SPICE. In Proceedings of the International Conference: Education $\mathcal{E}$ ICT in the New Millenium, Kuala Lumpur, Malaysia, 27 October, pp. 164-185.

Savery, J. R. \& Duffy, T.M. (1995). Problem-based learning: An instructional model and its constructivist framework. Educational Technology, September-October, 3138.

Schank, R. C., Berman, T. R. \& Macpherson, K. A. (1999). Learning by doing. In C. M. Reigeluth (Ed.), Instructional theories and models: A new paradigm of instructional theory (2nd ed), pp. 161-181. Mahwah, NJ: Lawrence Erlbaum.

Siaw, I. S. C. (2000). Fostering self-directed learning readiness by way of intervention in business education. In Proceedings at the 2nd Asia Pacific Conference on Problem-Based Learning: Education Across Disciplines, 4-7 December, Singapore. 
Shaziti, A. (2000). Network learning environment as a vehicle and support tool for integrating constructivism in the everyday classroom. In Proceedings of the International Conference: Education $\mathcal{E}$ ICT in the New Millenium, Kuala Lumpur, Malaysia, 27 October, pp. 41.

Suraya H. (2005). A framework for strategic future e-learning applications to support sustainable growth in the e-learning industry. In Proceedings of the International Conference on Multimedia and ICTs in Education (m-ICTE2005), 7-10 June, Caceres, Spain, pp 1-10.

Tai, X. L., Neo, M. \& Teoh, S. P. (2005). Using a multimedia project in the constructivist learning environment: Its implication on the student learning process. In Proceedings of the International Conference on Multimedia and ICTs in Education (m-ICTE2005), 7-10 June, 2005, Caceres, Spain.

Tan, O. S. (2000). Thinking skills, creativity and problem-based learning. In Preceedings in conjunction with the 2nd Asia Pacific Conference on Problem-Based Learning: Education Across Disciplines, 4-7 December, Singapore, pp.47-55.

Teo, R. \& Wong, A. (2000). Does problem based learning create a better student: A reflection? In Proceedings at the 2 nd Asia Pacific Conference on Problem-Based Learning: Education Across Disciplines, 4-7 December, Singapore.

Tway, L. (1995). Multimedia in action. AP Professional, MA.

Vygotsky, L. (1978). Mind in society: The development of higher pyschological processes. Cambridge, MA: Harvard University Press.

Wilson, B. G. (1995). Metaphors for instruction: Why we talk about learning environments. Educational Technology, 35(5), 25-30.

Winnips, K. \& McLoughlin, C. (2001). Six WWW based learner supports you can build. In C. Montgomerie \& J. Viteli (Eds.), Proceedings of Ed-Media 2001: World Conference on Educational Multimedia and Hypermedia, Tampere, Finland: AACE, pp. 2062-2067.

Wong, S. L., Kamariah, A. B. \& Tang, S. H. (2003). Differences in anxiety between IT competent and incompetent Malaysian pre-service teachers: Can a discrete IT course taught in a constructivist learning environment solve this problem? Turkish Online Journal of Educational Technology, 2(4). http: / / www.tojet.net/articles/244.htm

Yildirim, Z. (2005). Hypermedia as a cognitive tool: Student teachers' experiences in learning by doing. Educational Technology E Society, 8(2), 107-117. http: / / www.ifets.info/others / download_pdf.php?__id=27\&a_id=539

Zheng, R. \& Zhou, B. (2006). Recency effect on problem solving in interactive multimedia learning. Educational Technology E Society, 9(2), 107-118. http: / / www.ifets.info/ others / download_pdf.php?j_id=31\&a_id=636

Dr Mai Neo, Senior Lecturer, Dr Tse-Kian Neo, Senior Lecturer, and Gillian Xiao-Lian, Tutor, Centre for Innovative Education (CINE), Faculty of Creative Multimedia, Multimedia University, Cyberjaya, Malaysia. Email: kneo@pc.jaring.my 